\title{
PEMBENTUKAN DAERAH OTONOM PULAU SEBATIK DALAM PERSFEKTIF KEADILAN
}

\author{
Establishment of Autonomic Area of Sebatik Island in Justice Perspective \\ Aslan $^{1}$, Baso Madiong ${ }^{2}$, Almusawasir $^{2}$ \\ ${ }^{1}$ Magister Ilmu Hukum Program Pascasarjana, Universitas Bosowa \\ ${ }^{2}$ Program Studi Ilmu Hukum, Program Pascasarjana, Universitas Bosowa \\ Email: aslan@gmail.com \\ Diterima: 06 Januari 2021 \\ Dipublikasikan: 06 Juni 0221
}

\begin{abstract}
ABSTRAK
Berpegang pada asas desentralisasi, yaitu dalam penyelenggaraan pmerintahan di Indonesia, menyerahkan kekuasaan kepada kepala daerah untuk menyelenggarakan otonomi daerah, Negara kesatuan republik Indonesia. Undang-undang otonomi daerah telah mengalami beberapa kali perubahan, setelah diundangkannya pemerintah daerah nomor 23, tahun 2014, dengan adanya otonomi daerah diiharapkan dapat membuka peluang bagi setiap daerah untuk lebih mampu memberdayakan segala potensi yang dimiliki daerah dan masyarakat dalam mewujudkan kesejahteraan dan daerahnya kemajuan. Untuk itu, pemekaran Pulau Sebatik Sebatiksangat diharapkan masyarakat di pulau tersebut sehingga dapat mempermudah beberapa hal seperti proses administrasi, pelayanan kesehatan dan lain sebagainya. Dalam penelitian ini penulis mengumpulkan data melalui angket, observasi dan dokumentasi di Pulau Sebatik. Berdasarkan hasil hukum kepulauan sebatik maka layak dilakukan pembinaan karena syarat-syarat pembentukannya sudah terpenuhi, aspirasi masyarakat sebatik, dan potensi potensi daerah yang cukup. Daerah Otonom Pulau Sebatik sesuai dengan peraturan perundang-undangan dan aspirasi masyarakat telah terpenuhi Sehingga pelaksanaan pembentukan. Daerah Otonomi Pulau Sebatik masih kurang memadai, Terkait Sumber Daya Manusia Dalam Pembentukan.
\end{abstract}

Kata Kunci: Pembentukan, Daerah Otonom, Pulau Sebatik.

\begin{abstract}
Adhering to the principle of decentralization, like in the administration of government in Indonesia, hands over power to the regional head to carry out regional autonomy, the Unitary State of the Republic of Indonesia. The regional autonomy law has undergone several changes after the promulgation of the Regional Government Number 23 of 2014. With this regional autonomy, it is hoped that it will open up opportunities for each region to be more capable of empowering all the potential that the regions and communities have in realizing the welfare and progress of their regions. For this reason, the expansion of Sebatik Island is highly expected by residents on the island so as to facilitate several matters such as administrative processes, health services and so on. In this study the authors collected data through questionnaires, observations and documentation on Sebatik Island. Based on the results in the sebatik island law, it is appropriate for the formation to be carried out because the requirements for formation have been met, which are the aspirations of the sebatik community and the potential for regional potential that is sufficient. So that the implementation of the formation of the autonomous region of the Sebatik Island in accordance with statutory regulations and the aspirations of the community have been fulfilled. Those related to human resources, infrastructure, and capital in the formation of the Sebatik Island Autonomous Region are not yet adequate.
\end{abstract}

Keywords: Formation, Autonomous Region, Sebatik Island.

\section{PENDAHULUAN}

Negara Indonesia Terdiri dari berbagai pulau yang menganut asas desentralisasi dalam penyelenggaraan pemerintahan dengan memberikan keleluasaan kepada kepala daerah untuk menyelenggarakan otonomi daerah Negara Kesatuan Republik Indonesia Undang-Undang Nomor 23 Tahun 2014 Tentang Pemerintahan Daerah Di Indonesia merupakan dasar hukum penyelenggaraan otonomi daerah di Indonesia, (selanjutnya disebut Undang-Undang Nomor 23 Tahun 2014). Undang-undang otonomi daerah di Indonesia merupakan payung hukum bagi semua peraturan perundang-undang yang mengatur otonomi yang mengatur penyelenggaraanOtonomi daerah seperti peraturan pemerintah pusat, peraturan daerah, peraturan bupati dan lain sebagainya berdasarkan undangundang.

Undang-Undang otonomi daerah di Indonesia itu adalah implementasi dari ketentuan yang tercantum dalam Undang-Undang Dasar 1945 (UUD 1945) yang menyebutkan otonomi daerah sebagai bagian dari sistem tata negara Indonesia dan pelaksanaan pemerintahan di Indonesia. Otonomi daerah di Indonesia saat ini diatur dalam undang undang nomor 23 tahun 2014 setelah mengalami beberapa kali perubahan. Sesungguhnya undang undang otonomi daerah telah mengalami beberapa kali perubahan setelah disahkannya UU Nomor 23 tahun 2014 tentang pemerintah daerah

Dengan otonomi daerah ini diharapkan membuka peluang kepada setiap daerah untuk lebih mampu dalam memberdayakan segala potensi yang dimiliki daerah dan 
masyarakat dalam mewujudkan kesejahteraan dan kemajuan daerah mereka. Sejalan dengan harapan dan cita-cita dimaksud maka dalam rangka meningkatkan ekselarasi dan kualitas penyelenggaraan pemerintahan daerah sesuai dengan jiwa dan semangat otonomi daerah yang dituangkan dalam Undang-Undang Nomor 23 tahun 2014, maka dipandang perlu untuk melakukan pemekaran wilayah baik pada wilayah Kabupaten/Kota, Kecamatan maupun Desa. Pembentukan daerah dipandang sebagai sebuah terobosan untuk mempercepat pembangunan suatu daerah melalui peningkatan kualitas hidup dan kemudahan memperoleh pelayanan bagi masyarakat.

Pembentukan wilayah merupakan bagian dari upaya untuk meningkatkan kemampuan pemerintah daerah dalam memperpendek rentang kendali antara pemerintah pusat dan daerah sehingga meningkatkan efektifitas penyelenggaraan pemerintah dan pengelolaan pembangunan infrastruktur. Termasuk pula dengan pemekaran kota atau pembentukan Daerah Otonomi Baru (DOB) yang baru dimana pemekaran (DOB) bertujuan untuk meningkatkan kualitas pelayanan publik agar lebih baik dalam melayani masyarakat,meningkatkan perkonomian masyarakat dengan menggali potensi dari Pulau Sebatik tersebut, dan pemerataan pembangunan. Syarat pemekaran kota madya yang diatur melalui Peraturan Pemerintah Republik Indonesia Nomor 78 Tahun 2007 Tentang Tata Cara Pembentukan, Penghapusan, dan Penggabungan Daerah. Pasal 32 Ayat (1) UndangUndang Nomor 23 Tahun 2014 Tentang Pemerintah Daerah, menentukan bahwa pembentukan daerah berupa pemekaran daerah dan penggabungan daerah. berkaitan dengan pembentukan daerah, dalam Pasal 33 Ayat (1) UU No. 23 Tahun 2014 menentukan bahwa Persyaratan pemekaran daerah, pemecahan daerah provinsi, atau daerah kabupaten/kota menjadi dua atau lebih daerah baru atau penggabungan bagian daerah dari daerah yang bersanding dalam satu daerah provinsi menjadi satu daerah baru. Berkaitan dengan pemekaran daerah, secara filosofis bahwa tujuan pemekaran daerah ada dua kepentingan, yakni pendekatan pelayanan umum pemerintahan kepada masyarakat, untuk peningkatan kesejahteraan masyarakat daerah, serta memperpendek rentang kendali pemerintahan.

Pulau Sebatik salah satunya merupakan daerah terdepan dari Negara Indonesia karena wilayah Pulau Sebatik berada di perbatasan dengan Negara Malaysia sehingga daerah tersebut perlu diperhatikan pembangunannya oleh pemerintah daerah maupun pemerintah pusat untuk mewujudkan harapan masyarakat agar dilakukan pembentukan Kota Sebatik karena harapan itu sudah ada sejak tahun 2005 setelah wilayah Pulau Sebatik khususnya perairan ambalat ingin dikuasai oleh Negara Malaysia yang sempat memanas bahkan mahasiswa dari seluruh Indonesia melakukan protes bahkan sejumlah perguruan tinggi di indonesia diisukan akan mengusir mahasiswa Malaysia sebagai dampak dari memanasnya hubungan Indonesia - Malaysia di perairan ambalat, sehingga pada saat itu Presiden Susilo Bambang
Yudhoyono melakukan tinjauan langsung ke pulau sebatik. Tokoh masyarakat Sebatik sekaligus ketua Tim Wahana Pemekaran Sebatik, H. Herman mengatakan sejak 2005 lalu diwacanakan Sebatik menjadi Kota dan seluruh persiapan telah dilakukan termasuk melengkapi persayaratan administrasi, Namun meskipun Pulau Sebatik sudah memenuhi syarat untuk dimekarkan menjadi kota berdasarkan perundang-undangan yang berlaku akan tetapi kenyataan itu sulit untuk diwujudkan sehingga impian warga sebatik belum nyata sampai saat ini.

Kehidupan masyarakat sebatik sangat bergantung pada Negara Malaysia, terutama kebutuhan dasar warga perbatasan di Pulau Sebatik, Kabupaten Nunukan, Kalimantan Utara, tergantung pada produk Malaysia. Faktor tersebut tidak terlepas dari kedekatan kawasan sebatik dan kemudahan akses produk dari negara tetangga di Pulau Sebatik yang membuat warga perbatasan terjajah secara ekonomi. Koordinator Wacana Pemekaran Kota Sebatik, Kamal Soeryanto mengatakan, kemakmuran ekonomi merupakan indikasi percepatan pemekaran Lima Kecamatan di Pulau Sebatik menjadi perkotaan.

Pemekaran Pulau Sebatik sangat diharapkan masyarakat di pulau tersebut sehingga memudahkan beberapa hal seperti proses administrasi pengurusan Kartu Tanda Penduduk (KTP), memudahkan pelayanan kesehatan rujukan pasien yang harus menempuh perjalanan darat dan laut menuju rumah sakit umum. di Kota Nunukan. dalam kurun waktu yang lama bahkan pasien rujukan terkadang meninggal dalam perjalanan ke rumah sakit umum di kota kabupaten, dan masih banyak permasalahan lainnya.

Harapanya Sebatik secepatnya menjadi daerah otonom sehingga pemerintahan tidak lagi berada di luar pulau sebatik dengan tujuan mempercepat pembangunan daerah, baik dari infrastruktur, ekonomi, pendidikan keamanan, dan mengejar ketertinggalan dari kota tawau yang jauh sanggat maju dari pulau sebatik padahal pulau sebatik berhadapan langsung dengan kota tawau yang sangat terang, banyak Mall, bahkan sudah banyak gedung yang menjulang tinggi di kota tawau hal tersebut tentu saja membuat rasa iri masyarakat Pulau Sebatik.

Sebagai pulau yang paling terdepan dari Negara Indonesia seharusnya Pulau Sebatik lebih di pentingkan untuk dijadikan daerah maju sebagi citra Indonesia di perbatasan Negara dan merupakan ujung tombak ketahanan di daerah perbatasan sehingga masyarakat di perbatasan mengikuti perkembangan Negara jirannya yaitu Tawau Malaysia, selain itu ada rasa kecemburuan bagi masyarakat pulau sebatik sehingga banyak dari warga sebatik yang memilih menjadi warga Negara Malaysia. Masalah ini tentu menjadi perhatian semua pihak baik pemerintah daerah, dan pemerintah pusat untuk mendukung pembangunan di daerah perbatasan.

\section{METODE}

Dalam penelitian ini penulis melakukan di lima kecamatan yang berada di Pulau Sebatik, Kabupaten 
Nunukan, Kalimantan Utara. Sehingga bisa mendapatkan data yang akurat untuk memjawab persoalan pembentukan daerah otonom pulau sebatik sebagaimana pada judul tesis ini.

Teknik pengumpulan data pada penelitian ini adalah dengan cara mengunakan beberapa cara antara lain:

1. Dokumentasi

Dokumentasi dilakukan pada kegiatan penelitian lapangan oleh penulis

2. Pengamatan

Pengamatan dilakukan untuk melihat potensi Pulau Sebatik, baik dari sumber daya alam, pertanian, perikanan, dan kelyakan infrastruktur yang sudah ada sehingga bisa menjawab masalah pemekaran daerah pulau sebatik.

3. Angket

Angket adalah teknik pengumpulan data dengan cara mengajukan pertanyaan tertulis untuk dijawab secara tertulis pula oleh responden. Angket merupakan kumpulan pertanyaan-pertanyaan yang tertulis yang digunakan untuk memperoleh informasi dari responden dari lima kecamatan yang ada di pulau sebatik tentang kelayakan pemekaran pulau sebatik yang ia ketahui.

\section{HASIL DAN PEMBAHASAN}

Pelaksanaan Ketentuan Pembentukan Daerah Otonom di Pulau Sebatik

Pembentukan daerah otonom diatur dalam UU NO 23 Tahun 2014, penyelenggaraan pemerintahan daerah diarahkan untuk mempercepat terwujudnya kesejahteraan masyarakat melalui peningkatan pelayanan, pemberdayaan, dan peran serta masyarakat serta peningkatan daya saing pada daerah dengan lebih memperhatikan prinsip-perinsip demokrasi, pemerataan keadilan, dan kekhasan suatu daerah dalam sistem Negara Kesatuan Republik Indonesia.

1. Berdasarkan ketentuan Undang-Undang Nomor 23

Tahun 2014

Ketentuan pebentukan daerah otonom Pulau Sebatik harus sesuai dengan aturan hukum di Indonesia dalam UU NO 23 Tahun 2014 Tentang Pemerintahanh Daerah, ada bebarapa Pasal yang mengatur Pembentukan daerah sebagai berikut:

a. Pasal 1 angka 20 pembentukan daerah adalah penetapan status daerah pada wilayah tertentu. Pasal 1 angka 21 daerah persiapan adalah bagian dari satu atau lebih daerah yang bersanding yang dipersiapkan untuk dibentuk menjadi daerah baru. Sementara itu dalam Pasal 1 angka 41 partisipasi masyarakat adalah peran serta warga masyarakat untuk menyalurkan aspirasi, pemikiran, dan kepentinganya dalam penyelenggaraan pemerintahan daerah.

b. Pasal 31 Ayat (1) dalam pelaksanaan desentralisasi dilakukan penataan daerah.

Ayat (2) penataan daerah sebagaimana dimaksud pada ayat (1) ditentukan untuk:
1) Mewujudkan efektivitas penyelenggaraan pemerintahaan daerah

2) Mempercepat peningkatan kesejahteraan masyarakat

3) Mempercepat peningkatan kualitas pelayanan publik

4) Meningkatkan kualitas tata kelola pemerintahan

5) Meningkatkan daya saing nasional dan daya saing daerah, dan

6) Memelihara keunikan adat istiadat, tradisi, dan budaya daerah.

Ayat (3) penataan daerah sebagaimana dimaksud pada ayat (1) terdiri atas pembentukan daerah dan penyesuaian daerah.

Ayat (4) pembentukan daerah dan penyesuaian daerah sebagaimana dimaksud pada ayat (3) dapat dilakukan berdasarkan pertimbangan kepentingan strategis nasional.

c. Pasal 32 Ayat (1) pembentukan daerah sebagaimana dimaksud dalam Pasal 31 ayat (3) berupa:

1) Pemekaran daerah dan

2) Penggabungan daerah.

Ayat (2) pembentukan daerah sebagaimana dimaksud pada ayat (1) mencangkup pembentukan daerah provinsi dan pembentukan daerah kabupaten/kota.

d. Pasal 33 ayat (1) pemekaran atau pembentukan daerah sebagaimana yang dimaksud dalam pasal 32 ayat (1) huruf a berupa:

1) Pemisahan atau pemecahan daerah provinsi dan daerah kabupaten atau kota untuk menjadi dua daerah atau lebih daerah yang baru; atau

2) Menggabungkan pada wilayah daerah dari wilayah daerah yang bersanding pada daerah lainnya dalam suatu daerah provinsi menjadi satu daerah baru.

Ayat (2) pemekaran daerah atau pembentukan daerah yang dimaksud pada ayat (1) dilakukan melaliu dengan tahapan-tahapan yaitu daerah persiapan provinsi atau daerah kabupaten dan kota persiapan.

Ayat (3) suatu daerah pembentukan persiapan sebagaimana yang dimaksud dalam ayat (2) harus memenuhi syarat dasar dan administratife.

e. Pasal 34 Ayat (1) persyaratan dasar sebagaimana yang dimaksud dalam Pasal 33 ayat (3) meliputi:

1) Kewilayaan dasar Persyaratan; dan

2) Kapasitas daerah dasar persyaratan.

Ayat (2) Syarat dasar wilayah yang dimaksud dalam ayat (1) huruf a meliputi:

1) Minimal luas wilayah;

2) Minimal Jumlah Pendudunya;

3) Batas-batas pada wilayah;

4) Cakupan- cakupan pada wilayah dan

5) Batas usia pembentukan minimal pada daerah provinsi, daerah kabupaten/kota/, dan pada kecamatan. 
Huruf b yaitu kemampuan suatu daerah untuk berkembang dalam mewujudkan kesejahteraan untuk masyarakat. Ayat (3) Syarat dasar dalam hal kapasitas daerah sebagaimana yang dimaksud pada ayat (1)

f. Pasal 35 Ayat (1) luas suatu wilayah penduduk sebagaimana yang dimaksud dalam Pasal 34 AYAT (2) huruf a dan huruf b ditentukan berdasarkan pengelompokan pulau atau kepulauan.

Ayat (2) pengelompokan pulau atau kepulauan (2) ketentuan mengenai pengelompokanSebagaimana dimaksud pada ayat (1) Pemerintah diatur dalam peraturan. Ayat (3) huruf c dibuntikan pada titik koordinat dalam peta dasar, batas-batas wilayah yang dimaksud dalam Pasal 34 ayat (2).

g. Pasal 36.Ayat (1) syarat dasar kemampuan pada daerah yang dimaksud pada Pasal 34 ayat (3) dilihat pada parameternya:

1) Dilihat dari Geografinya.

2) Dilihat dari Demografinya.

3) Dilihat dari Keamanannya.

4) Dilihat dari Sosial politik, adat, dan tradisinya.

5) Dilihat dari Potensi ekonominya.

6) Dilihat dari Keuangan daerahnya, serta

7) Dilihat dari mampukah menyelenggaraan pemerintah.

Ayat (2) ukuran geografi yang dimaksud dalam ayat

(1) huruf b yaitu:

1) Lokasi calon ibu kotanya

2) Hidrografinya

3) Rawan terjadi bencana alam.

Ayat (3) yang dimaksud dari demografi dalam ayat (1) huruf b yaitu:

1) Kualitas pada sumber daya manusianya

2) Distribusi pada penduduknya

Ayat (4) yang dimaksud dari keamanan sebagaimana dalam ayat (1) huruf c yaitu:

1) Kejahatan umum atau criminal

2) Masalah dalam kelompok sosial sering konflik.

Ayat (5) yang dimaksud dari sosial politik, adat, dan tradisi dalam ayat (1) huruf d yaitu:

1) Sejauh mana kehadiran masyarakat pada pemilihan umum;

2) Konektivitas pada sosial, dan

3) Organisasi dalam masyarakat

Ayat (6) yang dimaksud dari potensi ekonomi dalam ayat (1) huruf e yaitu:

1) Kemampuan tumbuhnyaperekonomian

2) Potensi unggulan daerah.

Ayat (7) parameter keuangan daerah sebagaimana dimaksud pada ayat (1) huruf $f$ meliputi:

1) Kapasitas pendapatan asi daerah induk;

2) Potensi pendapatan asli calon daerah pesiapan; dan

3) Pengelolaan keuangan dan asset daerah.

Ayat (8) parameter kemampuan penyelenggaraan pemerintahan sebagaimana dimaksud pada ayat (1) huruf $g$ meliputi:

1) Aksesibilitas pelayanan dasar pendidikan;

2) Aksesibilitas pelayanan dasar kesehatan;
3) Aksesibilitas pelayanan dasar infrastruktur;

4) Jumlah pegawai aparatur sipil negara di daerah induk; dan

5) Rencangan rencana tata ruang wilayah daerah perisapan.

h. Pasal 37 persyaratan administrative sebagaimana yang dimaksud dalam Pasal 33 ayat (3) disusun dengan tata urutan sebagai berikut:

1) Untuk daerah provinsi meliputi:

(1) persetujuan bersama antara DPRD kabupaten/kota dengan bupati/walikota yang akan menjadi cakupan wilayah daerah persiapan suatu provinsi; dan

(2) persetujuan bersama antara DPRD provinsi induk dengan gubernur daerah provinsi yang induk.

2) Untuk daerah kabupaten/kota meliputi:

(1) keputusan musyawarah pada setiap desa yang akan menjadi cakupan wilayah daerah suatu kabupaten/kota;

(2) persetujuan bersama DPRD kabupaten/kota induk dengan bupati/wali kota daerah induk; dan

(3) persetujuan besama DPRD provinsi dengan gubenur dari daerah provinsi yang mencakupi daerah persiapan kabupaten/kota yang akan dibentuk.

i. Pasal 40 Ayat (1) Pendanaan penyelenggaraan pemerintahan pada daerah persiapan berasal dari:

1) Bantuan pengembangan daerah persiapan yang bersumber dari APBN;

2) Bagian pendapatan dari pendapatan asli daerah induk yang berasal dari daerah persiapan;

3) Penerimaan dari bagian dana perimbangan daerah induk; dan

4) Sumber pendapatan lain yang sah sesuai dengan ketentuan peraturan perundang-undangan. Kemudian Ayat (2) pendanaan penyelenggaraan pemerintahan pada daerah persiapan sebagaimana dimaksud pada ayat (1) ditetapkan delam anggaran pendapatan dan belanja daerah induk.

j. Pasal 49 Ayat (1) pembentukan daerah berdasarkan pertimbangan kepentingan strategis nasional sebagaimana dimaksud dalam Pasal 31 ayat (4) berlaku untuk daerah perbatasan, pulau-pulau terluar, dan daerah tertentu untuk menjaga kepentingan dan kedaulatan Negara Kesatuan Republik Indonesia.

Ayat (2) pembentukan daerah sebagaimana dimaksud pada ayat (1) harus dilakukan melalui tahapan daerah periapan provinsi atau daerah persiapan kabupaten/kota paling lama 5 (lima) tahun.

Ayat (3) Pembentukan Daerah Persiapan sebagaimana dimaksud pada ayat (2) harus memiliki Cakupan Wilayah dengan batas-batas yang jelas dan mempertimbangkan parameter pertahanan dan keamanan, potensi ekonomi, serta paramater lain yang memperkuat kedaulatan Negara Kesatuan Republik Indonesia. 
2. Berdasarkan Ketentuan Peraturan Pemerintah Republik Indonesia No. 78 Tahun 2007

Peraturan pemerintah republik Indonesia No. 78 tahun 2007 tentang tata cara pembentukan, penghapusan dan pengabungan daerah, sementara itu dalam Undang Undang Nomor 23 Tahun 2014 Tentang Pemerintahan Daerah sama- sama mengatur hal-hal yang menjadi persyaratan pembentukan daerah atau pemekaran daerah baru.

Sementara itu bunyi Pasal 16 sebagai berikut:

Pasal 16 Tata cara pemebentukan daerah kabupaten/kota sebagaimana dimaksud pada Pasal 2 ayat (4) huruf a dilaksanakan sebagai berikut:

Aspirasi sebagian besar masyarakat setempat dalam bentuk keputusan BPD untuk Desa dan Forum Komunikasi Kelurahan atau nama untuk kelurahan kabupaten atau kota pada daerah pembentukan.

Dewan Perwakilan Rakyat Daerah Kabupaten atau kota bisa mengambil keputuskan setuju atau menyetujui aspirasi sebagaimana dimaksud dalam huruf a dalam bentuk keputusan DPRD berdasarkan aspirasi sebagian besar masyarakat setempat yang diwakili oleh BPD untuk desa atau kata lain dan Forum Komunikasi Kelurahan untuk kelurahan atau nama lain.

\section{Aspirasi masyarakat}

Aspirasi masyarakat atau partisipasi masyarakat dalam proses pembentukan daerah otonom sangat penting seperti bunyi Pasal 2 huruf a. Aspirasi sebagian besar masyarakat setempat dalam bentuk keputusan BPD untuk Desa dan Forum Komunikasi Kelurahan atau nama untuk kelurahan kabupaten/kota yang akan dimekarkan. Aspirasi masyarakat menjadi indiktor penting sebelum dilakukanya pemekaran daerah sebatik.Jumlah keseluruhan penduduk Pulau Sebatik, 40.818 jiwa terbagi di lima kecamatan sebagai berikut:

a. Kecamatan Sebatik 4.464 jiwa.

b. Kecamatan Sebatik Utara 7.466 jiwa.

c. Kecamatan Sebatik Barat 7. 837 jiwa.

d. Kecamatan Sebatik Tengah 8. 348 jiwa

e. Kecamatan Sebatik Timur 12. 524 jiwa.

Total penduduk Pulau Sebatik berdasarkan data tahun 2018 sebanyak 40.641 jiwa.

pulau sebatik memang sudah menyampaikan langsung keinginan pemekaran daerah otonom pulau sebatik pada tahun 2005kepada Presiden Susilo Bambang yudhoyono yang akrab di sapa SBY saat beliau berkunjung ke pulau sebatik, pada tahun 2014 Presiden Jokowi juga melakukan kunjungan ke sebatik lagi-lagi masyarakat menuntut pembentukan DOB Sebatik kepada Presiden Jokowi dalam kesempatan itu jokowi menuturkan akan melakukan kajian untuk pembentukan Kota Sebatik, berbagia janji yang diberikan kepada warga sebatik setiap tahunnya berharap janji itu sudah bisa dilihat, bahkan di berbagai media eletronik maupun media cetak sering kali disebutukan sebatik paling lambat 2 tahun sperti yang diberitakan oleh Kaltara. Prokal. Co pada tahun 2016 sampai saat ini semua belum ada realisasi nyata.
Selain itu setiap tahunnya berbagai tuntutan masyarakat sebatik kepada pemerintah yang memberikan janji pemekaran kepada masyarakat sebatik, seiring berjalannya waktu Mahasiswa yang ada di sebatik maupun yang kuliah di luar pulau sebatik membentuk organisasi Forum Pemuda Percepatan Pembentukan DOB Sebatik (FPPDS) organisasi tersebut menjadi wadah aspirasi pemuda dalam menyampaikan visinya untuk pembentukan DOB Sebatik yang bertujuan agar para pemuda tetap dapat berkontribusi dalam pembentukan DOB Sebatik. Setiap tahun berbagia organisasi mahasiswa pulau sebatik melakukan aksi demostran sepertipada tahun 2012 dipelopori oleh mahasiswa pulau sebatik yang menuntut ilmu di Makassar Sulawesi Selatan, Yogyakarta dan lain sebaginya.

Selanjutnya berdasarkan wawancara dilapangan dengan bapak Safaruddin, SE, mengatakan bahwa "dari segi ekonomi pulau sebatik sudah sangat maju bisa dilihat di beberapa sektor yang ada misalnya sektor pertanian, perdagangan antar Negara, perikanan bahkan pertambangan. Kemudian perhotelan tempat-tempat hiburan masyarakat pulau sebatik juga sudah sangat baik, selanjutnya dibidang pariwisata pulau sebatik memiliki beberapa pariwisata yang sangat baik" sebatik sudah layak menjadi sebuah kota otonom hanya saja alokasi anggaran untuk mendukung pembentukan belum ada.

Kemudian berdasarkan wawancara dilapangan dengan bapak Drs. M.Ali.S, Mengatakan bahwa pulau sebatik, berdasarkan syarat-syarat pembentukan otonomi daerah sudah memenui syarat, dari wilayah, jumlah penduduk, dan lain sebagainya. Apa lagi kalau dilihat dari segi potensi daerah sudah sejak dulu ada hanya saja belum bisa dikelolah lebih baik lagi dikarenakan sarana penunjang untuk mengolah potensi daerah secara keseluruhan sudah pasti belum sepenuhnya, di sebatik ini yang sudah ada itu seperti Pabrik Kelapa Sawit Crude Palm Oil (CPO) kemudian kita juga sudah punya pabrik pengolahan ikan yang dibangun untuk mendukung pendapatan masyarakat pulau sebatik bahkan provinsi Kalimantan utara.

\section{Faktor Penghambat Pembentukan Daerah Otonom Pulau Sebatik}

Sumber daya manusia menjadi salah satu syarat pembentukan daerah otonom pulau sebatik, pada tahun 2016 pualu sebatik masih di kategorikan memiliki SDM yang masih terbatas baik secara kualitas maupun kuantitas potensi sumber daya manusia yang ada belum optimal di arahkan untuk menjawab tantangan yang ada di sebatik.

Pengembangan sumber daya manusia dalam mendukung pembentukan dearah otonom pulau sebatik sangat diharapkan akan tetapi putra dan putri terbaik pulau sebatik yang melanjutkan pendidikan sarjana S1, magister S2 bahkan Doktor S3 di bebagai perguruan tinggi di pulau kota tarakan, samarinda, Balikpapan, Makassar, Palu, kendari, Jakarta, Surabaya, bahkan di luar negeri seperti Malaysia, Australia, dan cina. Setelah selesai meraih gelarnya para putra dan putri terbaik itu 
lebih memilik bekerja di luar dari pulau sebatik dikarnakan belum ada lapangan pekerjaan yang sesuai dengan gelar bahkan jurusan yang mereka ambil sehingga mereka memutuskan bekerja diluar daerah seperti di nunukan, tarakan, samarinda, Balikpapan, Makassar, bahkan sampai di Jakarta.

Kurangnya sarana dan prasarana pendukung yang ada di wilayah calon Daerah Otonomi Baru untuk mendukung penyelenggaraan pemerintah Seperti Infrastruktur juga menjadi pendukung dalam usulan pembentukan daerah otonom. di pulau sebatik infrastruktur yang sudah ada antara lain, Jalan lingkar pulau sebatik sudah $100 \%$ jalan beraspal, kemudian listri juga hampir $90 \%$ sudah masyarakat gunakan, Pabrik Crude Palm Oil (CPO) yang menopang pendapatan masyarakat dan daerah dari pertanian kelapa sawit, pabrik pengolahan ikan yang dibangun untuk mendukung pendapatan masyarakat pulau sebatik bahkan provinsi Kalimantan utara, setiap ikan yanga akan di ekspor ke wilayah tawau Malaysia harus melalui pelabuhan perikanan sebatik karena posisi yang sangat streategis untuk lintas perdagangan antar Negara (Indonesia dan Malaysia), selain itu di pulau sebatik kedepannya akan dilakukan pengembangan industry pisang dan industri lainya, dan Pelabuhan Sungai Nyamuk atau pelabuhan sebatik yang dibangun sejak tahun 2005, pelabuhan ini memiliki panjang 2,7 kilometer ke laut mendekati garis batas Negara Indonesia dan Malaysia di lautan menjadikan pelabuhan ini sebagai ikon batu pada pintu gerbang masuk perbatasan. Pekerjaan Umum dan Perumahan Rakyat (PUPR) sedang malakukan pengembangan sejak 24 februari 2020 dan target selesai pada 17 juli 2021.

\section{KESIMPULAN DAN SARAN}

Bahwa pelaksanaan pembentukan daerah otonomi pulau sebatik secara peraturan perundang-undangan dan aspirasi masyarakat sudah terpenuhi, tetapi yang terkait dengan sumber daya manusia, infrastruktur, dan modal belum memadai, karena telah terpenuhi semua persyaratan tersebut dalam teori pemekaran daerah, dan desentralisasi, Yang terkait dengan sumber daya manusia, infrastruktur, dan modal dalam pembentukan daerah otonomi pulau sebatik belum memadai, karena belum memadai semua persyaratan tersebut dalam teori dasar pembentukan daerah otonom yang harus sesuai dengan dasar dimana bisa diperhatikan terutama kepada sumber daya manusia, sarana dan prasarana dan fasilitas yang ada.

\section{DAFTAR PUSTAKA}

Alim, M., Ismail, I., \& Nurkaidah, N. (2020). Optimalisasi Kinerja Unit Pelaksana Tingkat Daerah Balai Latihan Kerja Dinas Tenaga Kerja Dan Transmigrasi Kabupaten Majene. Jurnal Paradigma Administrasi Negara, 2(1), 9-11.
Departemen Pendidikan dan Kebudayaan, 2001, Kamus Besar Bahasa Indonesia, Balai Pustaka, Jakarta

Moh. Rofii Adji Sayketi, 2008, Peran Masyarakat dalam Otonomi Daerah" Cempaka Putih. Klaten.

Peraturan Pemerintah Republik Indonesia Nomor 78 Tahun 2007 Tentang Tata Cara Pembentukan, Penghapusan, dan Penggabungan Daerah

Undang-Undang Nomor 23 Tahun 2014 Tentang Pemerintahan Daerah 